\title{
MANAGEMENT OF ALLUVIAL FORESTS INCLUDED IN NATURA 2000 91E0* HABITAT TYPE IN MARAMUREŞ MOUNTAINS NATURE PARK
}

Oana DANCI*

* “Lucian Blaga” University of Sibiu, Faculty of Sciences, Department of Ecology and Environmental Protection, Dr. Ioan Raţiu Street 5-7, Sibiu, Romania, RO-550012, oanadanci@gmail.com

DOI: 10.1515/trser-2015-0057

KEYWORDS: alluvial forests, habitat management, riverbanks, sediments. ABSTRACT

The Natura 2000 habitat type 91E0* Alluvial forests of Alnus glutinosa and Fraxinus excelsior (Alno-Padion, Alnion incanae, Salicion albae) include three subtypes of forests. In the Maramureș Mountains Nature Park (MMNP) the alluvial forests are represented by Alnus incana forest situated on the banks of mountain rivers. Starting from 2007, 70\% of the MMNP is also a Natura 2000 site of community interest. In the standard form for the site are listed 18 Natura 2000 habitat types, but that of alluvial forests 91E0* is not listed either due to an error or lack of available research data. Our study seeks to provide information regarding this high conservation value habitat such as: structure, distribution, management measures and monitoring protocol. The purpose of this paper is to offer a management tool for this conservation value habitat which is also exposed to human impact more than any other priority habitat in MMNP.

RÉSUMÉ: Gestion des forêts alluviales faisant partie du type d’habitat Natura 2000 91E0* dans le Parc Naturel des Montagnes de Maramureș.

Le type de habitat Natura 2000 91E0* des Forêts alluviales avec Alnus glutinosa et Fraxinus excelsior (Alno-Padion, Alnion incanae, Salicion albae) regroupe trois catégories de forêts, les forêts alluviales du Parc Naturel Les Montagnes de Maramureș (PNMM) étant principalement représentées par des aulnes blanches, Alnus incana, situées au bord des rivières. Depuis 2007, 70\% de la surface du PNMM fait partie du site Natura 2000 ROSCI Les Montagnes Maramureș. Dans le formulaire standard du site existent 18 habitats Natura 2000, mais l'habitat 91E0* Forêts alluviales avec Alnus glutinosa et Fraxinus excelsior n'en fait pas partie, probablement à cause d'une erreur ou de l'absence d'études détaillées dans la région. Grâce à cette étude nous souhaitons contribuer avec des informations sur: la structure, la distribution, le suivi de gestion et la surveillance de cet habitat à haute valeur de conservation. Le but du présent travail est de fournir des outils de gestion pour cet habitat qui fait partie des habitats prioritaires les plus exposés à l’impact anthropogénique.

REZUMAT: Managementul pădurilor aluviale incluse în Habitatul Natura 2000 de tip 91E0* din Parcul Natural Munţii Maramureșului.

Tipul de habitat Natura 2000 91E0* Păduri aluviale cu Alnus glutinosa și Fraxinus excelsior (Alno-Padion, Alnion incanae, Salicion albae) include trei subtipuri de păduri, în Parcul Natural Munții Maramureșului (PNMM) pădurile aluviale fiind reprezentate în principal de aninișuri de anin alb, Alnus incana, situate pe malurile râurilor. Începând din anul 2007, $70 \%$ din suprafața PNMM este inclusă în situl Natura 2000 ROSCI Munții Maramureșului. În formularul standard al sitului sunt incluse 18 habitate Natura 2000, dar habitatul 91E0* Păduri aluviale cu Alnus glutinosa și Fraxinus excelsior nu este inclus, probabil din cauza unei erori sau din lipsa studiilor în zonă. Prin acest studiu dorim să contribuim cu informații precum: structura, distribuția, măsuri de management și monitorizare a acestui habitat cu valoare ridicată de conservare. Scopul lucrării este de a oferi instrumente de management pentru acest habitat cu valoare conservativă, care este și cel mai expus impactului uman dintre habitatele prioritare. 


\section{INTRODUCTION}

The "Habitats" Directive (Council Directive 92/43/EEC) is a European Community legislative instrument in the field of nature conservation that establishes a common framework for the conservation of wild animal and plant species and natural habitats of Community importance; it provides for the creation of a network of special areas of conservation, called Natura 2000, to "maintain and restore, at favourable conservation status, natural habitats and species of wild fauna and flora of Community interest". Annex I of "Habitats" Directive lists today 218 European natural habitat types, including 71 priority habitat types. In the meaning of the directive, priority habitat is a habitat type in danger of disappearance and whose natural range mainly falls within the territory of the European Union (***, 2003).

The object of our study is the priority habitat type 91E0* Alluvial forests with Alnus glutinosa and Fraxinus excelsior (Alno-Padion, Alnion incanae, Salicion albae) in Maramureș Mountains Nature Park and Natura 2000 site of community interest site.

Starting with the CORINE Programme, the term habitat has become familiar in Europe: senso stricto, it means place of life, representing the abiotic environment where a distinct organism or biocoenosis exists. This environment is a geotope with a correspondence to an ecotope. This ecotope transformed by the biocoenosis is a biotope. The habitat is defined by this meaning in classic biology and ecology works. However, the meaning of habitat given by the CORINE programme and then by the other classification systems which followed, was, in fact, an ecosystem, that is a "habitat" senso stricto and the corresponding biocoenosis which occupies it (Doniţă et al., 2005, 2006). This evidently results from the name and description of the habitat types where references are made not only to the features of the ecotope, but especially to those of the biocoenoses occupying the respective sites (Gafta and Mountford, 2008). In this paper we will use the term habitat with the meaning given by the Habitats Directive and by Doniță et al., 2005.

Maramureș Mountains Nature Park is one of the largest nature parks in Romania (133,354 ha), declared as a protected area by the Governamental Decision 2151/2004 and it has its own administration starting from 2005. Maramureș Mountains Nature Park is a protected landscape IUCN Category V, created to protect and sustain important landscapes and the associated nature conservation and other values created by interactions with humans through traditional management practices.

Protected landscape is defined by IUCN Global Protected Areas Programme as a protected area where the interaction of people and nature over time has produced an area of distinct character with significant ecological, biological, cultural and scenic value: and where safeguarding the integrity of this interaction is vital to protecting and sustaining the area and its associated nature conservation and other values.

Starting from 2007, about 70\% of MMNP is also Natura 2000 site of communitarian interest. In the standard form of the site are listed 18 Natura 2000 habitats, but the habitat of alluvial forest 91E0* is not listed due to an error or due to the lack of available research. Our study comes to provide information regarding this high conservation value habitat such as: structure, distribution, management measures and monitoring protocol.

For an appropriate management of a nature park, the internal zoning is needed. It includes special conservation zone, where no human interventions are allowed, the sustainable management area where the nature resources are managed in a traditional way and the human activities sustainable development area which includes the human communities. The alluvial forests in MMNP are mostly situated in the area of human activities sustainable development area where the anthropic pressure is increased. 
By our current study we intended to offer the park administration a management tool for this habitat. So we elaborated a distribution map, described the structure of this habitat, identified anthropic pressures, developed a set of management recommendation and a monitoring protocol in order to monitor its conservation status in time.

We also provided a template for a data collection form which helps in standardisation and easy interpretation of data.

The purpose of this paper is to provide a management tool for this high conservation value habitat which is also exposed to human impact more than any other priority habitat in MMNP.

\section{MATERIAL AND METHODS}

Identification of habitat types was performed by the recognition of phytocoenoses that characterises them. That means by considering the significant (generally prevailing) species and ecological and/or coenological markers, as well as by recognition of the characteristics of the site, first by geographical location, altitude, relief, rock and soil.

By mapping the habitat types, we employed the following cartographic materials: Ortophotoplans, satellite images, topographic maps (1:25,000), forest maps (1:20,000 and 1:50,000). The information on these maps has been transposed into a GIS (Geographical Information System) system. We set the limits of the habitats to the changes of the phytocoenoses and sites characterizing them. The positioning of habitats on the map is performed by means of the GPS coordinates collected from the field, by using the GPS Trimble ProXH receptor with a zephir antenna and GPS Trimble ProXT. The data were processed in ArcGIS 9.3 programme.

We proposed a monitoring protocol in order to evaluate the evolution of the habitat in time and also to evaluate the effectiveness of implementing the management plan. The protocol is directly oriented to the reality in the field and is designed according to the MMNP Administration resource, human and material. Some management measures are recommended in order to assure the maintenance of the conservation status of this habitat type or improve it.

\section{RESULTS AND DISCUTION}

At national level the priority Natura 2000 habitat 91E0* Alluvial forests of Alnus glutinosa and Fraxinus excelsior (Alno-Padion, Alnion incanae, Salicion albae) includes three subtypes of forests: first, forest of Alnus gutinosa and Fraxinus excelsior situated in wet meadows in the plains and hills vegetation floor; second, Alnus incana forest situated on banks of mountain rivers; and, third, wooded galleries composed of tall trees of the species Salix alba, S. fragilis and Populus nigra along rivers of the mountains, foothills and plains. In our study area we identified the first two habitat types in the field (Danci, 2011). 


\section{Habitat description}

91E0*Alluvial forest with Alnus glutinosa and Fraxinus excelsior - R4401 South-East Carpathian forest of grey alder (Alnus incana) with Telekia speciosa habitat subtype

Corresponds to:

NATURA 2000: 91E0*Alluvial forest with Alnus glutinosa and Fraxinus excelsior (Alno-Padion, Alnion incanae, Salicion albae)

EMERALD: -

CORINE: -

PAL.HAB: 44.214 Eastern Carpathian grey alder galleries

EUNIS: G1.1214 Eastern Carpathian grey alder galleries

Plant associations: Telekio speciosae-Alnetum incanae Coldea (1986) 1991

Distribution in Maramureș Mountains Nature Park: The phytocoenoses of the association Telekio speciosae-Alnetum incanae were identified and mapped in the riverbed of Bistra, Frumuşeaua, Repedea and Rica valleys (Fig. 2); the mapping process continues in the park area (Fig. 4).

Structure: The phytocoenoses are identified by boreal and European species. The tree layer is exclusively composed of grey alder (Alnus incana) with a few examples of spruce (Picea abies), fir (Abies alba) and beech (Fagus sylvatica). The coverage is aproximatively 80$100 \%$ and the height is $15-25 \mathrm{~m}$ at the age of 50 . The shrub layer, which is missing or poorly developed, includes Salix triandra, Corylus avellana, Lonicera xylosteum and Prunus padus. The herb layer is well developed, and dominated by Petasites albus and Telekia speciosa (Fig. 1) (Doniţă et al., 2005).

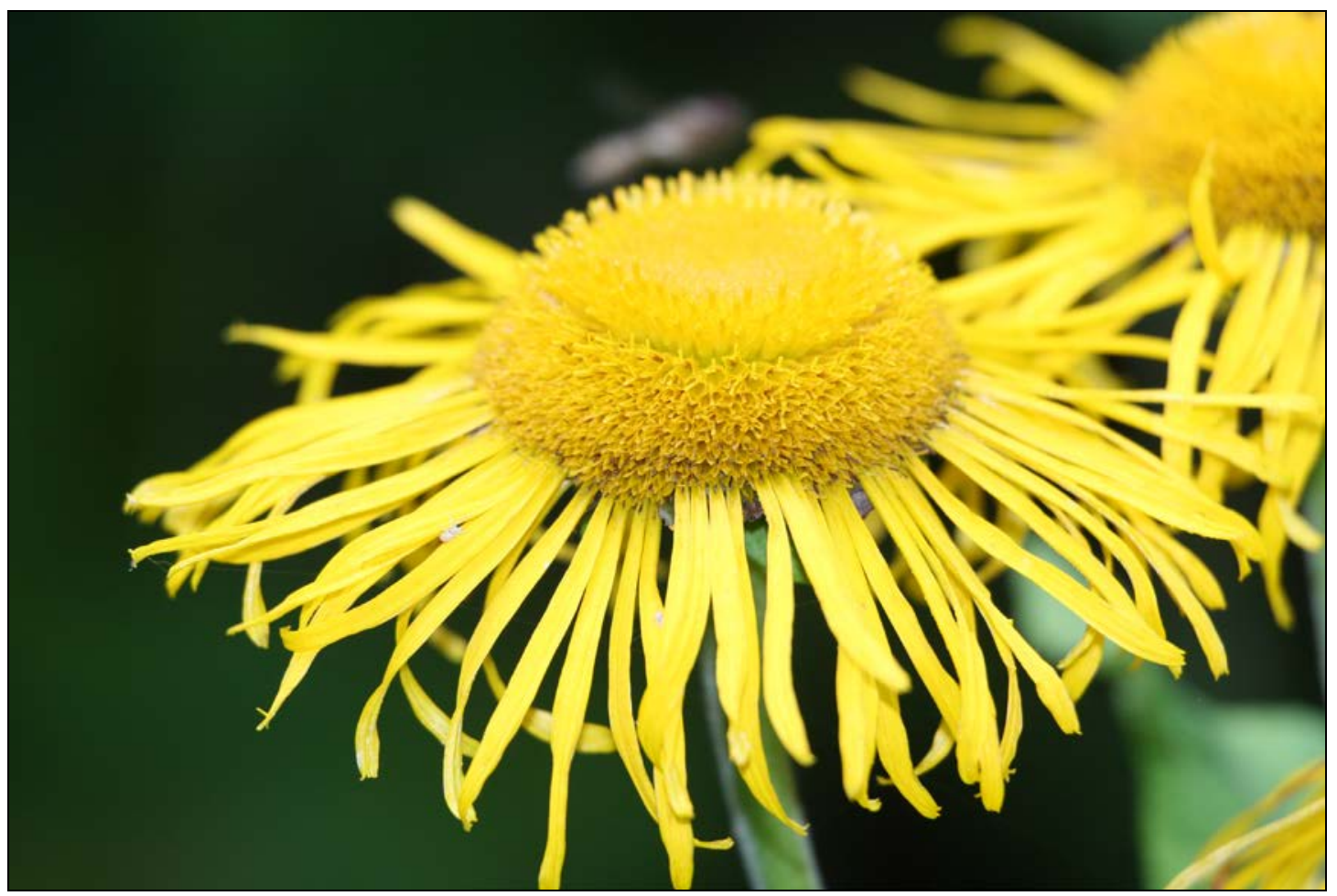

Figure 1: Telekia speciosa. 
Conservation value: very high.

Composition:

- Identifying species: Alnus incana.

- Characteristic species: Telekia speciosa.

- Other important species: Angelica sylvestris, Aegopodium podagraria, Athyrium filix-femina, Carex remota, Cardamine impatiens, Chaerophyllum hirsutum, Circaea lutetiana, Cirsium oleraceum, Dryopteris filix-mas, Glechoma hederacea, Geranium phaeum, Festuca gigantea, Impatiens noli-tangere, Mentha longifolia, Myosotis sylvatica, Matteuccia struthiopteris, Oxalis acetosella, Petasites hybridus, P. kablikianus, Ranunculus repens, Salvia glutinosa, Stachys sylvatica, Stellaria nemorum, Tussilago farfara, etc.

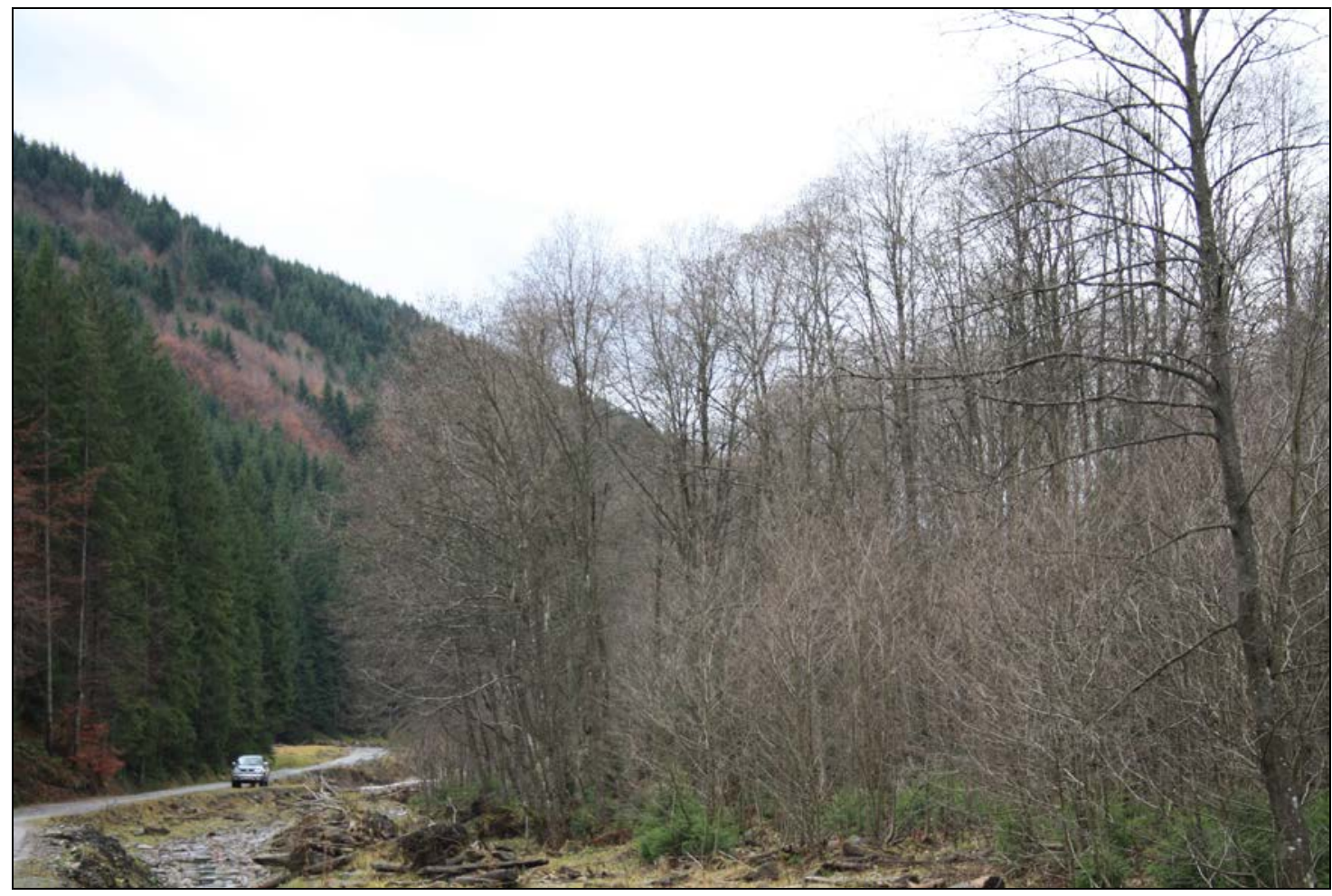

Figure 2: Grey alder forest in Rica Valley, Maramureș Mountains Nature Park.

91E0* Alluvial forest with Alnus glutinosa and Fraxinus excelsior - R4402 Forest of black alder (Alnus glutinosa) with Stellaria nemorum on hilly meadows habitat subtype.

Corresponds to:

NATURA 2000: 91E0*Alluvial forest with Alnus glutinosa and Fraxinus excelsior (AlnoPadion, Alnion incanae, Salicion albae)

EMERALD: -

CORINE: -

PAL.HAB: 44.323 Pre-Carpathian stream ash - alder woods

EUNIS: G1.2123 Pre-Carpathian stream ash - alder woods

Plant associations: Stellario nemori-Alnetum glutinosae (Kästner 1938) Lohm. 1957 
Distribution in MMNP: Phytocoenosis of plant association Stellario nemori-Alnetum glutinosae were identified on 44 ha on the riverbed of Vaser Valley (Fig. 3) and Novăț Valley (Fig. 4).

Structure: Phytocoenoses are identified by European nemoral species and boreal species. The tree layer comprises black alder (Alnus glutinosa) exclusively or mixed with narrow-leaved ash (Fraxinus angustifolia), white elm (Ulmus laevis), black and white poplar (Populus nigra, P. alba), willows (Salix fragilis, S. alba) and field maple (Acer campestre). The coverage is around $70-80 \%$ and the height is $20-25 \mathrm{~m}$ at 100 years old. The shrub layer is moderately developed and is made up of Cornus sanguinea, Sambucus nigra, Corylus avellana, Viburnum opulus, Crataegus monogyna and Humulus lupulus. The herb and subshrub layer often contains Rubus caesius and Aegopodium podagraria.

Conservation value: very high.

Species composition:

- Identifying species: Alnus glutinosa.

- Characteristic species: Alnus glutinosa, Stellaria nemorum, Ranunculus ficaria.

- Other important species: Agrostis stolonifera, Bidens tripartita, Brachypodium sylvaticum, Carex remota, Circaea lutetiana, Eupatorium cannabinum, Galium aparine, Glecoma hederacea, Geranium robertianum, Impatiens noli-tangere, Lamium galeobdolon, Matteuccia struthiopteris, Mentha longifolia, Myosotis scorpioides, Petasites albus, Ranunculus repens, Salvia glutinosa, Sambucus ebulus, Solanum dulcamara, Tussilago farfara, etc. (Doniţă et al., 2005).

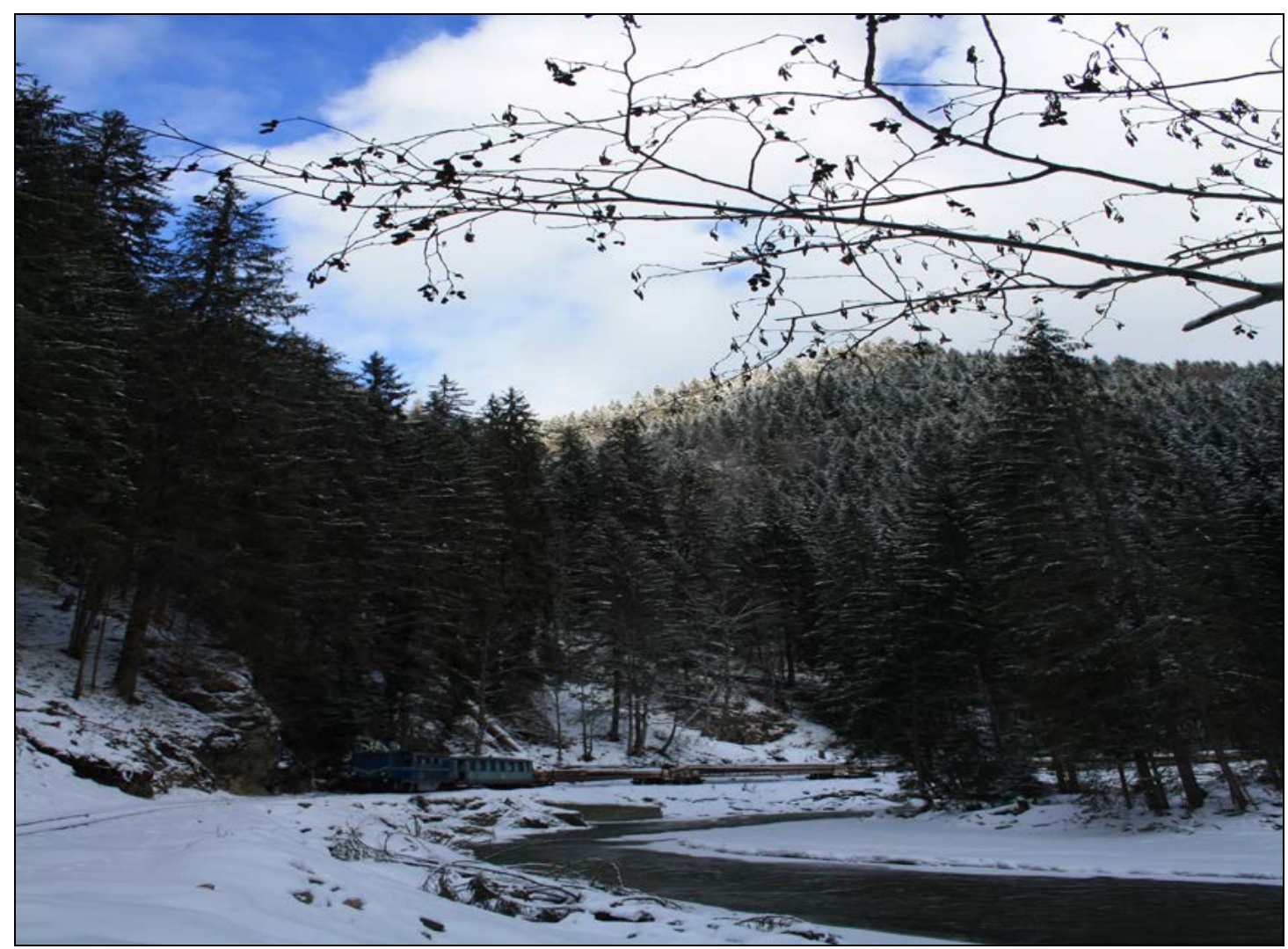

Figure 3: Black alder trees in the Vaser Valley. 


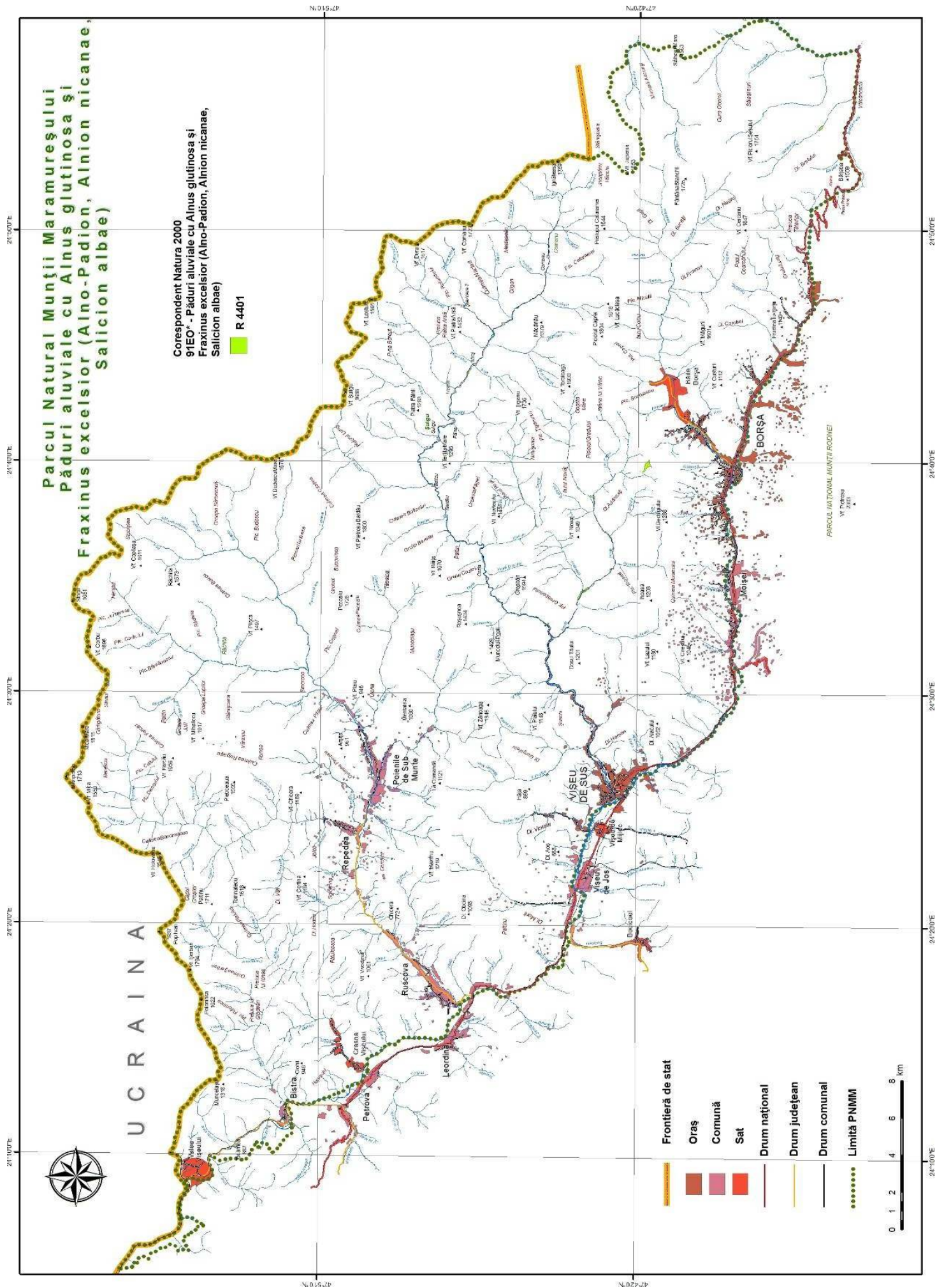

Figure 4: Partial distribution map of alder alluvial forest in Maramureș Mountains Nature Park. 


\section{Monitoring}

Alluvial forests of alder have high conservation value not on account of the species that identify this habitat, but due to the functions of the habitat such as: flood prevention and regulation, an ecological corridor for large mammals, a feeding and nesting habitat for bird species. The presence of this habitat is directly related to the presence of water floods and new sediment deposits. Due to the fact that most of the alluvial forest included in 91E0* habitat in Maramureș Mountains Nature Park is situated in the human communities development area and also due to its high conservative value, we decided to provide instruments for monitoring the conservation status of this habitat. The evolution of conservation status is the reflection of the effectiveness of the management of the park (Elzinga et al., 2001). The monitoring protocol (Tab. 1) is designed to fit to the conditions of MMNP and it is adapted to the human and material resources of the park administration.

Table 1: Alder alluvial forest monitoring protocol in Maramureș Mountains Nature Park.

\begin{tabular}{|c|c|}
\hline Protocol number & 3 (for MMNP) \\
\hline Title & $\begin{array}{l}\text { Alder alluvial forest monitoring } \\
\text { protocol }\end{array}$ \\
\hline Priority & 1 \\
\hline Monitoring question & $\begin{array}{l}\text { Is the conservation status of alder } \\
\text { alluvial forest maintained in MMNP? }\end{array}$ \\
\hline Indicator & $\begin{array}{l}\text { Presence of plant association } \\
\text { characteristic to 91E0* habitat type, } \\
\text { edifying species, characteristic species. }\end{array}$ \\
\hline Justify & $\begin{array}{l}\text { The habitat of alluvial forest with Alnus } \\
\text { glutinosa and Fraxinus excelsior (Alno- } \\
\text { Padion, Alnion incanae, Salicion albae) } \\
\text { is a priority habitat at European level. It } \\
\text { has an important role in fixing the } \\
\text { sediments, gravels, riverbank } \\
\text { stabilisation, prevention or minimising } \\
\text { the effect of floods. }\end{array}$ \\
\hline Attributes & Modifies in species composition. \\
\hline \multicolumn{2}{|l|}{ Sampling protocol } \\
\hline Number of sampling plots & $\begin{array}{l}\text { Three sampling plots on every important } \\
\text { water course riverbanks in MMNP. }\end{array}$ \\
\hline Distribution and selection of sampling plots & $\begin{array}{l}\text { Along the riverbanks, where the surface } \\
\text { is enough. }\end{array}$ \\
\hline Sampling size & $20 \times 20 \mathrm{~m}$ \\
\hline Sampling plots location & $\begin{array}{l}\text { The GPS coordinates of the sampling } \\
\text { plots will be recorded and marked on the } \\
\text { map. It is recommended to mark on the } \\
\text { field the corners of the sampling plot } \\
\text { with wooden sticks. }\end{array}$ \\
\hline
\end{tabular}


Table 1 (continued): Alder alluvial forest monitoring protocol in Maramureș Mountains Nature Park.

\begin{tabular}{|l|l|}
\hline Data collection protocol & \\
\hline $\begin{array}{l}\text { Detailed information related to the data that will } \\
\text { be collected }\end{array}$ & $\begin{array}{l}\text { Species composition, anthropisation } \\
\text { degree, regeneration degree. }\end{array}$ \\
\hline Data collection format & $\begin{array}{l}\text { Format is standard, the data collection } \\
\text { sheet is an annex of this protocol } \\
\text { (Tab. 2) }\end{array}$ \\
\hline Quality assurance and standardisation & $\begin{array}{l}\text { The same staff will collect data at every } \\
\text { survey on all valleys. }\end{array}$ \\
\hline Frequency and period of collecting data & Once per year. \\
\hline Data management and analyse & $\begin{array}{l}\text { Data will be stored both on paper (data } \\
\text { collection field sheet) and electronic } \\
\text { (.xls) format. } \\
\text { Additional copies will be kept in safe } \\
\text { place. }\end{array}$ \\
\hline Data storage and management of information & $\begin{array}{l}\text { The data collected will be annually } \\
\text { analysed. }\end{array}$ \\
\hline Data analyse procedure & $\begin{array}{l}\text { A report regarding the conservation } \\
\text { status of the habitat will be elaborated } \\
\text { annually. It will include a map with the } \\
\text { sampling plots marked. According to } \\
\text { the result, the park biologist will } \\
\text { elaborate management } \\
\text { recommendations. The report will be } \\
\text { short and compendious. }\end{array}$ \\
\hline $\begin{array}{l}\text { Reporting format and results communication } \\
\text { the management }\end{array}$ & $\begin{array}{l}\text { The MMNP biologist and two rangers. } \\
\text { 20 field days and five days for data } \\
\text { analyse and reporting. }\end{array}$ \\
\hline Resources allocation & $\begin{array}{l}\text { Car, fuel, maps, GPS, photo camera, } \\
\text { plant identification guide }\end{array}$ \\
\hline Human resources & $\begin{array}{l}\text { The responsibility for maintenance and } \\
\text { calibration belongs to the monitoring } \\
\text { team. }\end{array}$ \\
\hline Eime resources & Maintenance and calibration of equipment \\
\hline
\end{tabular}


Table 2: Annex to the protocol 3. Data collection sheet for evaluation of the conservation status on alder alluvial forest.

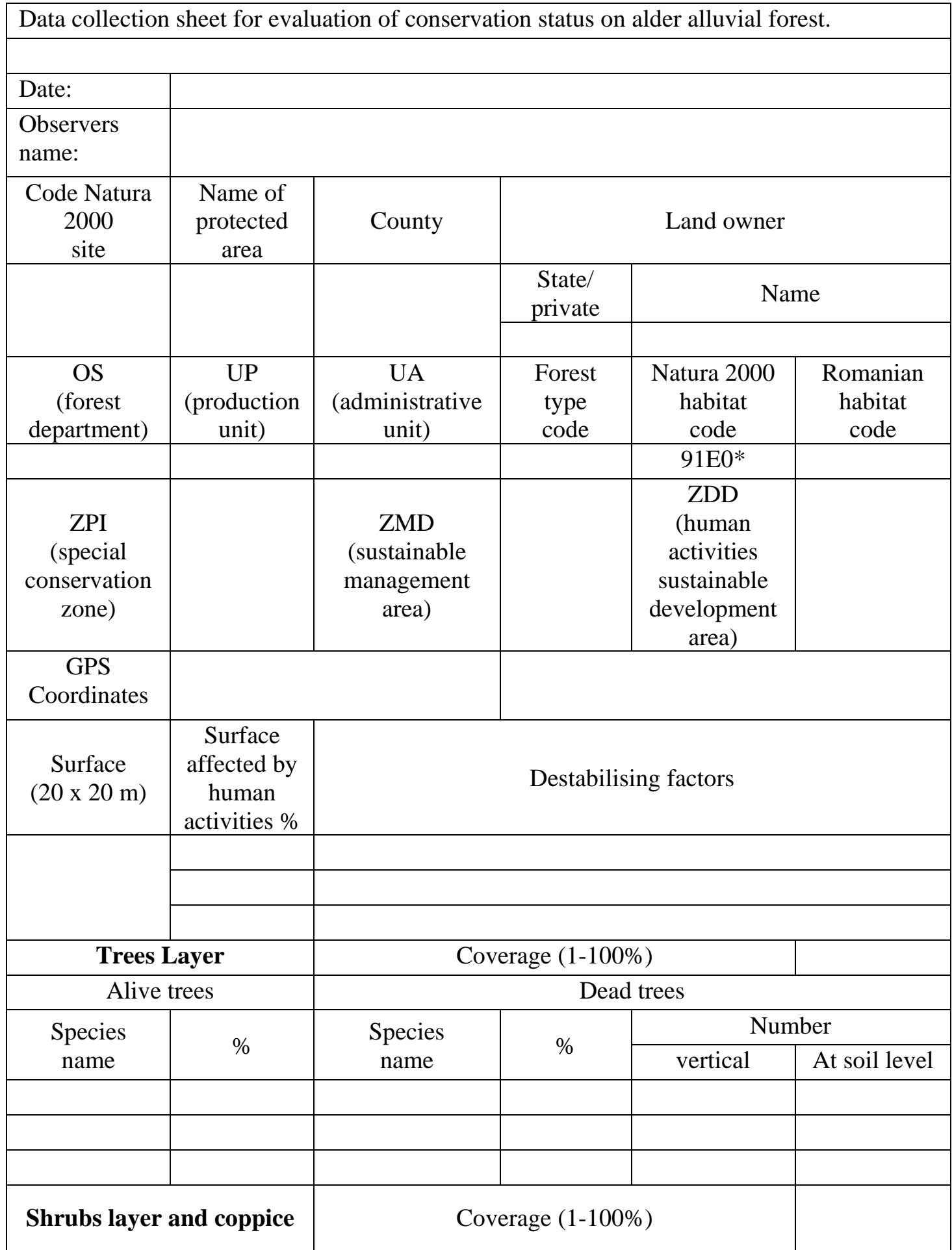


Table 2 (continued): Annex to the protocol 3. Data collection sheet for evaluation of conservation status on alder alluvial forest.

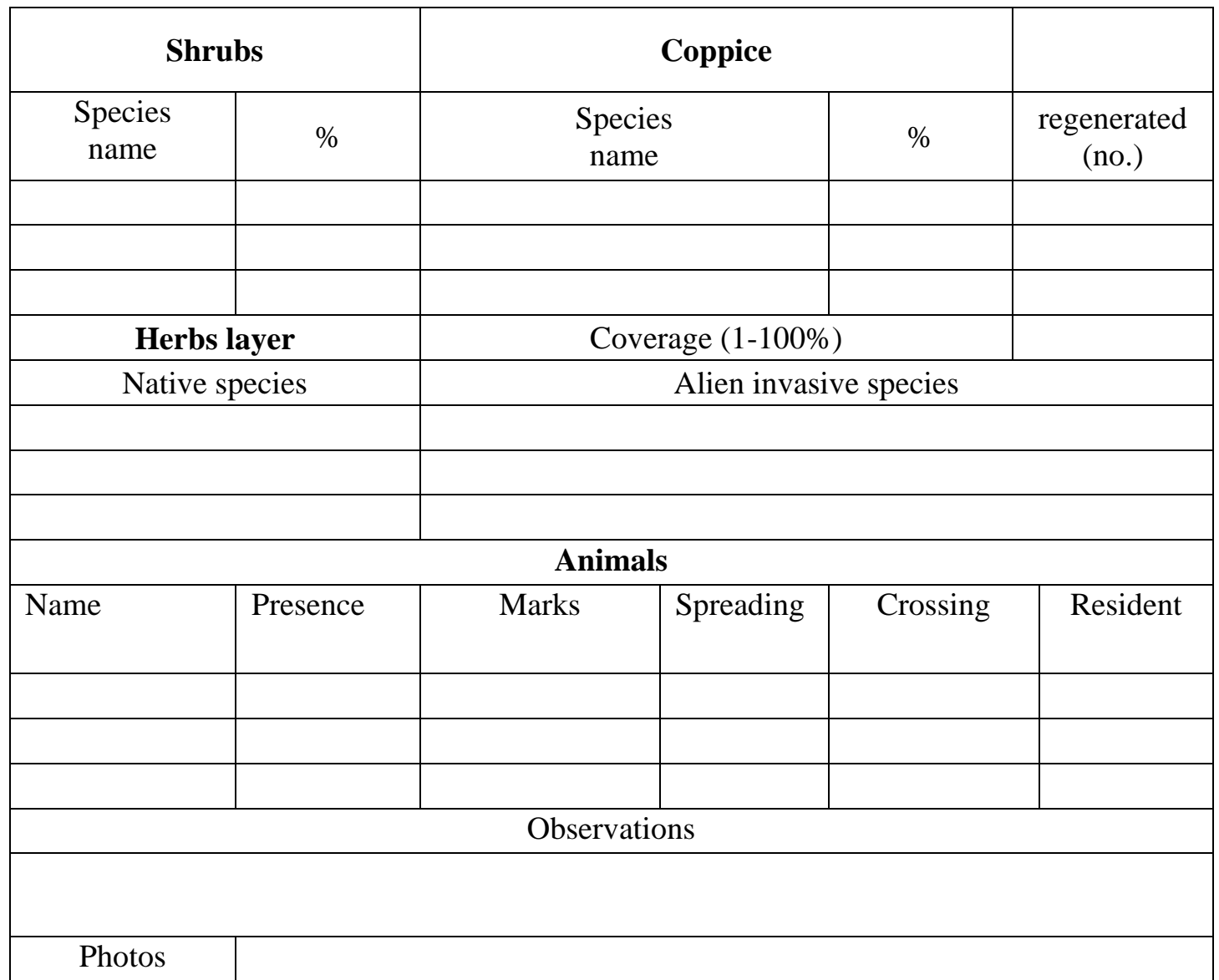

In order to establish the conservation status of one habitat or species it is necessary to establish some parameters that will be analysed. For alluvial forests of grey and black alder in MMNP we selected, according to Stăncioiu et al. (2008), and adapted some parameters to the specific of this priority habitat and to the specific of the study area.

In table 3 we proposed some parameters in order to interpret the data collected in the field for the conservation status evaluation. These parameters represent quantifiable indicators that can be used by the park administration.

If all parameters are according to the accepted limit, we can accept that the conservation status is at least good. If one or a few parameters are exceeding the limits, the conservation status should be determined in accordance with the importance of the parameter and proportionally to the destabilisation. 
Table 3: Indicators used for data interpretation (Stăncioiu, 2009 - modified).

\begin{tabular}{|c|c|c|}
\hline Parameters & Observations & Accepted level \\
\hline \multicolumn{3}{|c|}{ Surface } \\
\hline Surface dynamics & Habitat loss & $\operatorname{maxim} 5 \%$ \\
\hline \multicolumn{3}{|c|}{ Trees layer } \\
\hline Species composition & $\begin{array}{l}\text { According to the identifying } \\
\text { plant association }\end{array}$ & Minim 70\% \\
\hline Non-native species & $\%$ in the composition & Maximum 20\% \\
\hline Regeneration & Seeds & minimum $40 \%$ \\
\hline Coverage & canopy & Minimum 70\% \\
\hline Number of dead trees & vertical & Minimum one dead tree/ha \\
\hline $\begin{array}{l}\text { Number of dead trees on } \\
\text { putrefaction }\end{array}$ & At soil & Minimum one dead tree/ha \\
\hline \multicolumn{3}{|c|}{ Seedling } \\
\hline Species composition & $\begin{array}{l}\text { According to the identifying } \\
\text { plant association }\end{array}$ & Minimum 70\% \\
\hline Coverage & Canopy and seedlings & Minimum 70\% \\
\hline Non-native species & $\%$ in the composition & Maximum 20\% \\
\hline Regeneration & Seeds & minimum 50\% \\
\hline \multicolumn{3}{|c|}{ Coppice } \\
\hline Species composition & $\begin{array}{l}\text { According to the identifying } \\
\text { plant association }\end{array}$ & Minimum 70\% \\
\hline Non-native species & $\%$ in the composition & Maxim 20\% \\
\hline \multicolumn{3}{|c|}{ Herbs layer } \\
\hline Species composition & $\begin{array}{l}\text { According to the identifying } \\
\text { plant association }\end{array}$ & Minimum 70\% \\
\hline $\begin{array}{l}\text { Non-native species } \\
\text { Invasive alien species }\end{array}$ & \% in the composition & Maxim 20\% \\
\hline \multicolumn{3}{|c|}{ Disturbances } \\
\hline $\begin{array}{l}\text { Stress factors, limitative } \\
\text { situations. }\end{array}$ & $\%$ of surface affected & Maxim $10 \%$ \\
\hline
\end{tabular}

\section{CONCLUSIONS}

The priority habitat 91E0* Alluvial forest with Alnus glutinosa and Fraxinus excelsior is represented in Maramureș Mountains Nature park by two of the three habitats subtypes in Romania: R4401 South-East Carpathian forest of grey alder (Alnus incana) with Telekia speciosa and R4402 Forest of black alder (Alnus glutinosa) with Stellaria nemorum on hilly meadows.

The structure and distribution of the habitat in MMNP represents the basis for elaborating the monitoring protocol. The monitoring protocol that we have elaborated is designed to fit the parks needs to increase the conservation status. A data collecting sheet was done in order to assure the standardisation of the process of data collection and to assure more accurate data from the field. We also analysed some parameters that can help in order to interpret the data collected in the field and to establish the conservation status of the habitat. Monitoring protocol, data collection sheet and indicators used in data interpretation were tested by us in the field. 
Even if the 91E0* Habitat is not listed in the standard form of Natura 2000 Maramureș Mountains communitarian interest site, it exists in the field and its importance and conservation value are very high. Monitoring instruments provided by this paper can be used by the MMNP Administration for monitoring and management of this habitat and can be included in reviewed Maramureș Mountains Nature Park Management Plan.

\section{ACKNOWLEDGEMENTS}

This paper presents a part of the results of my PhD Thesis; for the scientific coordination of the thesis and for his permanent support I am grateful to Mr. Cristea V. Also, I would like to thank to my former colleagues from Maramureș Mountains Nature Park administration for their help and understanding. 


\section{REFERENCES}

1. Danci O., 2011 - Maramureș Mountains: habitat types, conservation and their management, $\mathrm{PhD}$ Thesis, 186. (in Romanian)

2. Doniţă N., Popescu A., Păucă-Comănescu M., Mihăilescu S. and Biriş I.-A., 2005 - Habitate din Romania, Edit. Tehnică Silvică, Bucureşti, 496. (in Romanian)

3. Doniţă N., Popescu A., Păucă-Comănescu M., Mihăilescu S. and Biriş I.-A., 2006 - Habitatele din România, Modificări conform amendamentelor propuse de România şi Bulgaria la Directiva Habitate (92/43/EEC), Edit. Tehnică Silvică, Bucureşti, 95. (in Romanian)

4. Elzinga C., Salzer D., Willoughby J. and Gibbs J., 2001 - Monitoring plant and animal populations, Blackwell Science, 360.

5. Gafta D. and Mountford O. (eds), 2008 - Manual de interpretare a habitatelor Natura 2000 din Romania, Edit. Risoprint, Cluj-Napoca, 101. (in Romanian)

6. Stăncioiu P. T., Lazăr G., Tudoran G. M., Candrea-Bogza Ş. B., Predoiu G. and Şofletea N., 2008 - Habitate prioritare alpine, subalpine şi forestiere din România. Măsuri de gospodărire, Edit. Universităţii „Transilvania”, Braşov, 184. (in Romanian)

7. $* * *, 2003$ - Manuel d'interpretetion des habitats de l'Union Européene, Commision Européene DG Environnement, 132. (in French) 